NOTE

\title{
Lipid extraction in stable isotope analyses of juvenile sea turtle skin and muscle
}

\author{
Thaisa F. Bergamo ${ }^{1,2}$, Silvina Botta ${ }^{2,3, *}$, Margareth Copertino ${ }^{1,2}$ \\ ${ }^{1}$ Laboratório de Ecologia Vegetal Costeira, Instituto de Oceanografia, Universidade Federal do Rio Grande - FURG, CP 474, \\ Rio Grande, RS 96203-900, Brazil \\ ${ }^{2}$ Programa de Pós-Graduação em Oceanografia Biológica, Instituto de Oceanografia, \\ Universidade Federal do Rio Grande - FURG, CP 474, Rio Grande, RS 96203-900, Brazil \\ ${ }^{3}$ Laboratório de Ecologia e Conservação da Megafauna Marinha, Universidade Federal do Rio Grande - FURG, CP 474, \\ Rio Grande, RS 96203-900, Brazil
}

\begin{abstract}
Studies involving various aspects of the biology and ecology of sea turtles have successfully applied stable isotope analysis. In many of these studies, the chemical extraction of ${ }^{13} \mathrm{C}$-depleted lipids of sea turtle tissues has been used as a standard protocol, often without testing whether the time-consuming lipid removal is required. Furthermore, this chemical procedure may unpredictably modify $\delta^{15} \mathrm{~N}$ values, probably due to the loss of proteins associated with lipid structures, thus reinforcing the need for testing the isotopic consequence of the chemical removal of lipids. This study aimed to evaluate the effects of lipid extraction on skin and muscle $\mathrm{C}$ and $\mathrm{N}$ isotopic values of juvenile green turtles Chelonia mydas. We analyzed paired $\delta^{13} \mathrm{C}$ and $\delta^{15} \mathrm{~N}$ values from lipid-extracted and non-lipid-extracted samples of skin and muscle of 15 juvenile green turtles. Lipid extraction was performed using a mixture of chloroform and methanol. A significant increase was found in $\delta^{13} \mathrm{C}$ values after lipid extraction for muscle $(\sim 0.5 \%)$, but not for skin. C:N ratios were not correlated with the change in $\delta^{13} \mathrm{C}$ values in either tissue. $\delta^{15} \mathrm{~N}$ values were not affected by lipid extraction in either tissue. The difference found in $\delta^{13} \mathrm{C}$ values between control and lipid-extracted muscle samples may be biologically significant. On the other hand, the lipid extraction of skin samples does not appear to be necessary in the case of juvenile green turtles. This procedure needs to be tested in green turtles in other life stages.
\end{abstract}

KEY WORDS: Green turtle $\cdot$ Chelonia mydas $\cdot$ Stable isotope analysis $\cdot$ Carbon $\cdot$ Nitrogen $\cdot \delta^{13} \mathrm{C} \cdot$ $\delta^{15} \mathrm{~N} \cdot$ Lipid extraction

\section{INTRODUCTION}

Stable isotope analysis (SIA) of animal tissue carbon $\left(\delta^{13} \mathrm{C}\right.$ values $)$ and nitrogen $\left(\delta^{15} \mathrm{~N}\right.$ values $)$ has been largely used to study the trophic ecology and habitat use of several taxa, including marine megafauna (e.g. seabirds, Cherel et al. 2005; sea turtles, Arthur et al. 2008; sharks, Carlisle et al. 2015; marine mammals, Drago et al. 2015). The method is

\footnotetext{
*Corresponding author: silbotta@gmail.com
}

based on the principle that the isotopic composition in the tissues of consumers reflects the mixture of the isotopic composition present in the different dietary items consumed (DeNiro \& Epstein 1978, 1981). The $\delta^{15} \mathrm{~N}$ values predictably increase with increasing trophic level (DeNiro \& Epstein 1981, Minagawa \& Wada 1984) and consequently, they are used as indicators of a consumer's trophic position (Post 2002, McCutchan et al. 2003, Vanderklift 
\& Ponsard 2003). On the other hand, $\delta^{13} \mathrm{C}$ values vary little along the food chain and are mainly used to infer primary sources in a food web (McCutchan et al. 2003).

In recent years, several studies using SIA have addressed the issue of the effects of lipids on the isotopic composition of tissue carbon (e.g. Lesage et al. 2010, Ruiz-Cooley et al. 2011, Ryan et al. 2012). Due to differences in the biochemical pathways during synthesis, lipids may be depleted in ${ }^{13} \mathrm{C}$ relative to other major constituents, such as proteins (DeNiro \& Epstein 1977). Such differences among protein and lipid metabolism (Martínez del Rio et al. 2009) can bias the interpretation of stable isotope values and result in misleading diet reconstructions, especially when based on tissues with a significant amount of fat (Ricca et al. 2007). Therefore, lipids are usually removed from tissues by either chemical lipid extraction or mathematical correction using speciesand tissue-specific equations (e.g. Logan et al. 2008, Elliott et al. 2014). Chemical extraction of lipids is generally effective, yielding isotopic values of carbon that can be considered free of the influence of these biomolecules (Post et al. 2007, Logan et al. 2008, Medeiros et al. 2015), resulting in increased values of $\delta^{13} \mathrm{C}$ compared to samples without extraction. However, several studies have reported unexpected changes in $\delta^{15} \mathrm{~N}$ values after lipid extraction (Sotiropoulos et al. 2004, Ricca et al. 2007, Logan et al. 2008), which is believed to be a consequence of the loss of proteins associated with lipid structures, such as lipid-membrane proteins (Sweeting et al. 2006). Therefore, testing the effects of lipid removal on both $\delta^{13} \mathrm{C}$ and $\delta^{15} \mathrm{~N}$ values is highly relevant before applying SIA to address questions about diet and trophic ecology.

Due to the high correlation between the values of the carbon to nitrogen ( $\mathrm{C}: \mathrm{N})$ ratio and the percentage of lipids, the $\mathrm{C}: \mathrm{N}$ ratio itself has been used as an indicator of tissue lipid content for numerous tissues and organisms (e.g. Post et al. 2007). Following this, samples with $\mathrm{C}: \mathrm{N}>3.5$ are considered to have a high lipid content (Post et al. 2007), making chemical extraction, or the use of normalization equations, necessary (Sweeting et al. 2006, Post et al. 2007). However, some studies found no support for the relationship between the bulk C:N ratio and the lipid percentage in organisms such as fish (Fagan et al. 2011), marine mammals (Wilson et al. 2014, Yurkowski et al. 2015), sea turtles (Medeiros et al. 2015), and invertebrates (Kiljunen et al. 2006). Therefore, the need for lipid extraction should be tested empirically before con- sidering the tissue as free of lipid interference, even for tissues with C: $\mathrm{N}<3.5$ (Fagan et al. 2011, Yurkowski et al. 2015).

Studies involving various aspects of the biology and ecology of sea turtles have successfully applied SIA (Arthur et al. 2008, Lemons et al. 2011, Thomson et al. 2012, González Carman et al. 2014). In many of these studies, the lipid extraction of sea turtle tissues has been used as a standard protocol, often without testing the extraction efficiency (i.e. lipid removal) and interference on $\delta^{15} \mathrm{~N}$ values (Revelles et al. 2007, Cardona et al. 2009). On the other hand, other authors decided not to extract lipids mainly based on C:N $<3.5$ values (Tomaszewicz et al. 2015, Prior et al. 2016).

Considering that the methodology used in preparing the samples can influence the results and, consequently, the interpretation of isotopic data, we analyzed the effect of lipid extraction on the isotope values of $\mathrm{C}$ and $\mathrm{N}$ in skin and muscle of juvenile green turtles Chelonia mydas. We determined (1) whether the chemical removal of lipids from these tissues increases their $\delta^{13} \mathrm{C}$ values, thus evidencing the presence of lipids in the sample, and (2) whether this procedure significantly affects the $\delta^{15} \mathrm{~N}$ values, either by increasing or decreasing them. The goal of the study was to assess the need for extracting lipids from skin and muscle samples of juvenile sea turtles.

\section{MATERIALS AND METHODS}

\section{Collection and sample preparation}

The samples of green turtles $(n=15)$ used in this study were from dead, stranded animals found along the southern coast of Rio Grande do Sul, Brazil $\left(31^{\circ} 20^{\prime} \mathrm{S}\right.$ to $\left.33^{\circ} 45^{\prime} \mathrm{S}\right)$ between May 2013 and June 2014. The decomposition stage of the specimens was assessed and classified according to Duarte et al. (2011). All animals used were classified into Stages 1 or 2 (fresh carcass or initial decomposition, respectively). Stable isotope composition was considered not to be affected by these decomposition stages as evidenced by previous work (Payo-Payo et al. 2013). For each turtle, curved carapace length (CCL) was measured from the nuchal notch to the posteriormost tip of the carapace with a measuring tape (Bolten 1999). Individuals with CCL $<115 \mathrm{~cm}$ were considered to be juveniles according the mean size of nesting females from Brazil (Almeida et al. 2011). Samples of skin and muscle tissue of the right fore flipper (Revelles et al. 2007) were collected with for- 
ceps and stainless steel razor blades, placed in labeled plastic bags, and then stored frozen at $-20^{\circ} \mathrm{C}$.

Paired skin and muscle samples were thawed, rinsed with distilled water, and dried in an oven at $60^{\circ} \mathrm{C}$ for $24 \mathrm{~h}$. Each tissue sample $(15$ skin and 15 muscle) was divided into 2 parts and subjected to 2 treatments: with and without lipid extraction. Samples of the first group were extracted by a Soxhlet reflux using chloroform:methanol (2:1) for two $8 \mathrm{~h}$ cycles (Folch et al. 1957, Revelles et al. 2007). After the extraction, samples were washed with distilled water and dried in an oven at $60^{\circ} \mathrm{C}$ for $48 \mathrm{~h}$. All samples (with and without extraction) were then ground to a fine powder with a mortar and pestle, weighed (between 0.5 and $0.9 \mathrm{mg}$ ) on a precision scale (AUY 220, Shimadzu), and stored in $5 \times 9 \mathrm{~mm}$ tin capsules.

For the determination of the $\delta^{13} \mathrm{C}$ and $\delta^{15} \mathrm{~N}$ ratios, all samples were sent to the Stable Isotope Core Laboratory at Washington State University (USA), and analyzed by a continuous flow isotope ratio mass spectrometer (Delta PlusXP, Thermo Finnigan). A conventional delta notation $(\delta)$ in parts per thousand $(\%)$ was used to express the stable isotope ratios of the samples in relation to that of standards:

$$
\delta X=\left[\left(\mathrm{R}_{\text {sample }} / \mathrm{R}_{\text {standard }}\right)-1\right]
$$

where $X$ is ${ }^{13} \mathrm{C}$ or ${ }^{15} \mathrm{~N}$, and $\mathrm{R}$ denotes the heavier: lighter isotope ratio $\left({ }^{13} \mathrm{C}:{ }^{12} \mathrm{C}\right.$ or $\left.{ }^{15} \mathrm{~N}:{ }^{14} \mathrm{~N}\right)$ in the sample $\left(\mathrm{R}_{\text {sample }}\right)$ and standard $\left(\mathrm{R}_{\text {standard }}\right)$. The standard was Vienna Pee Dee Belemnite for $\delta^{13} \mathrm{C}$ values and atmospheric $\mathrm{N}_{2}$ for $\delta^{15} \mathrm{~N}$ values. No replicates of the samples were analyzed; however, the analytical precision based on the standard deviations around the means for internal laboratory standards run at set intervals was high $\left(\leq 0.1 \%\right.$, both for $\delta^{13} \mathrm{C}$ and $\left.\delta^{15} \mathrm{~N}\right)$, thus results are still expected to be significant. The $\mathrm{C}: \mathrm{N}$ ratio was calculated by dividing the $\% \mathrm{C}$ by $\% \mathrm{~N}$.

\section{Statistical analysis}

The assumptions of data normality and homoscedasticity were verified using the Shapiro-Wilk and Bartlett tests, respectively. To test whether there was a significant difference in the values of $\delta^{13} \mathrm{C}$, $\delta^{15} \mathrm{~N}$, and the C:N ratio between samples of skin and muscle, and within lipid-extracted and control (i.e. without lipid extraction) samples within the same tissue, data were analyzed using paired $t$-tests, with a significance level of $\alpha=0.05$. Simple linear regression models were used to test the relationship between $\Delta \delta^{13} \mathrm{C}$ (difference between $\delta^{13} \mathrm{C}$ values of con- trol and lipid-extracted samples) and the C:N ratio of control samples for muscle and skin in order to test whether the $\mathrm{C}: \mathrm{N}$ ratio of untreated samples could be an indicator of the need for lipid removal. All analyses were performed in the statistical environment R v. 3.1.3 (R Development Core Team 2013).

\section{RESULTS}

The CCL of the green turtles analyzed varied between 35 and $47 \mathrm{~cm}$ (mean \pm SD: $39.8 \pm 3.6 \mathrm{~cm}$ ), thus all were considered juveniles. The $\delta^{13} \mathrm{C}$ values were significantly lower in muscle than in skin samples (paired $t$-tests, $t=0.14, \mathrm{p}<0.001$ for lipid-extracted and control samples). Nitrogen isotope values, on the other side, did not differ between tissues $(t=0.14, \mathrm{p}=$ 0.13 and $t=0.14, \mathrm{p}=0.14$, for lipid-extracted and control samples, respectively). C: $\mathrm{N}$ ratios were significantly higher in muscle samples $(t=0.14, \mathrm{p}<0.001$, for lipid-extracted and control samples). The values of $\delta^{13} \mathrm{C}$ in muscle were significantly lower in control samples than in lipid-extracted samples $(t=6.2, \mathrm{p}<$ 0.0001). Mean $\delta^{13} \mathrm{C}$ differences between control and lipid-extracted samples $\left(\Delta \delta^{13} \mathrm{C}\right)$ was $0.51 \%$. However, this difference was mainly driven by 3 samples that showed an increase of $>0.5 \%$ after lipid extraction, with all other samples being less modified by the treatment (i.e. $\Delta \delta^{13} \mathrm{C}<0.5 \%$; Fig. 1). Skin samples did not show differences between treatments $(t=0.88, \mathrm{p}=0.39)$, with a mean $\Delta \delta^{13} \mathrm{C}$ of $0.09 \%$ (Fig. 1, Table 1). Neither the regression between the $\mathrm{C}: \mathrm{N}$ ratio of control samples and $\Delta \delta^{13} \mathrm{C}$ for muscle or for skin were significant $\left(\mathrm{r}^{2}=0.06, \mathrm{p}=0.38\right.$ and $\mathrm{r}^{2}=$ $0.05, \mathrm{p}=0.40$, for muscle and skin, respectively).

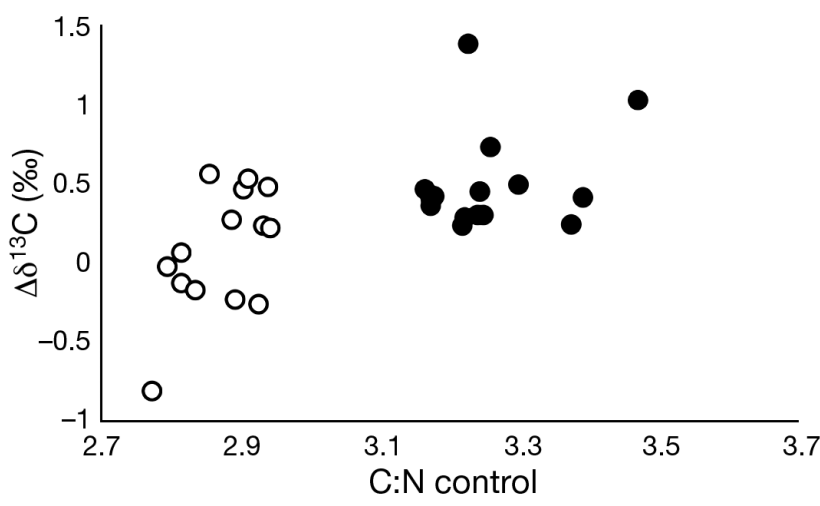

Fig. 1. Relationship between $\Delta \delta^{13} \mathrm{C}$ (the difference between carbon isotope values) of control and lipid-extracted samples of skin (open circles) and muscle (black circles) of juvenile green turtles Chelonia mydas and the C:N ratio of control samples 
Table 1. Carbon $\left(\delta^{13} \mathrm{C}\right)$ and nitrogen $\left(\delta^{15} \mathrm{~N}\right)$ isotope values and $\mathrm{C}: \mathrm{N}$ ratios of muscle and skin of juvenile green turtles Chelonia mydas. Mean $\pm \mathrm{SD}$, minimum, and maximum values for the control (without lipid extraction) and lipid-extracted samples are reported

\begin{tabular}{|c|c|c|c|c|c|c|c|c|c|}
\hline \multirow{2}{*}{$\begin{array}{l}\text { Treat- } \\
\text { ment }\end{array}$} & \multicolumn{3}{|c|}{$-\delta^{13} \mathrm{C}(\%)-$} & \multicolumn{3}{|c|}{$\longrightarrow \delta^{15} \mathrm{~N}(\%) \longrightarrow$} & \multicolumn{3}{|c|}{$\mathrm{C}: \mathrm{N}$} \\
\hline & Mean \pm SD & Min & Max & Mean $\pm \mathrm{SD}$ & Min & Max & Mean \pm SD & Min & $\operatorname{Max}$ \\
\hline \multicolumn{10}{|c|}{ With extraction } \\
\hline Muscle & $-17.2 \pm 0.9$ & -18.4 & -15.5 & $11.7 \pm 1.2$ & 9.2 & 14.3 & $3.1 \pm 0.1$ & 2.7 & 3.2 \\
\hline Skin & $-15.2 \pm 0.6$ & -16.2 & -14.4 & $12.0 \pm 0.9$ & 10.3 & 13.6 & $2.8 \pm 0.1$ & 2.6 & 3.0 \\
\hline \multicolumn{10}{|l|}{ Control } \\
\hline Muscle & $-17.7 \pm 0.8$ & -18.7 & -16.2 & $11.3 \pm 1.4$ & 8.4 & 13.5 & $3.2 \pm 0.1$ & 3.2 & 3.5 \\
\hline Skin & $-15.3 \pm 0.6$ & -16.1 & -14.2 & $11.9 \pm 1.1$ & 9.4 & 13.2 & $2.9 \pm 0.1$ & 2.8 & 3.2 \\
\hline
\end{tabular}

that may include such outliers. Moreover, Lesage et al. (2010) calculated the predicted error in prey contribution using Bayesian stable isotope mixing models and found that an error of $0.5 \%$ due to sample treatment of consumer tissues would introduce a considerable bias depending on the degree of distinctiveness of the end members of the mixing model. Thus, although small $\Delta \delta^{13} \mathrm{C}$ values were found for juvenile sea turtle muscle samples, we recommended testing for the effect of lipid extrac-

Lipid extraction had no significant effect on the average values of $\delta^{15} \mathrm{~N}$ found for both tissues $(t=1.7$, $\mathrm{p}=0.11$ and $t=1.05, \mathrm{p}=0.31$ for muscle and skin, respectively; Table 1). The mean difference between $\delta^{15} \mathrm{~N}$ values of control and lipid-extracted samples $\left(\Delta \delta^{15} \mathrm{~N}\right)$ was 0.38 and $0.16 \%$ for muscle and skin, respectively. The extraction of lipids significantly modified the values of the C:N ratios of muscle samples $(t=3.46, \mathrm{p}<0.05)$ but not $\mathrm{C}: \mathrm{N}$ ratios of skin $(t=$ 2.09, $\mathrm{p}=0.05 ;$ Table 1).

\section{DISCUSSION}

Our results show that the effect of lipid extraction (chloroform:methanol solution) on the $\delta^{13} \mathrm{C}$ values was significant when analyzing the muscle (increase in $\sim 0.5 \%$ o) of juvenile Chelonia mydas, but did not affect the $\delta^{13} \mathrm{C}$ values of the skin. Further, significantly lower $\delta^{13} \mathrm{C}$ and higher $\mathrm{C}: \mathrm{N}$ ratios were found in muscle samples in relation to those found in skin samples. This difference could be interpreted as evidence of a higher lipid content of muscle samples (Post et al. 2007). However, this difference was maintained when $\delta^{13} \mathrm{C}$ values in lipid-extracted samples were compared. Similar differences between these 2 tissues were also reported for loggerhead turtles Caretta caretta (Revelles et al. 2007) and for pinnipeds (Todd et al. 2010). Therefore, other factors such as the carbon isotope composition of individual amino acids within tissues (Martínez del Rio et al. 2009, Fagan et al. 2011) may play a role in the differences found between $\delta^{13} \mathrm{C}$ values of both tissues.

We found a mean difference of $\sim 0.5 \%$ in $\delta^{13} \mathrm{C}$ values of muscle, where some of the samples (see Fig. 1) showed increases in carbon isotope values higher than $0.5 \%$ after lipid extraction; thus, caution is required when deciding on the need for lipid extraction, especially when dealing with low sample sizes tion when using $\delta^{13} \mathrm{C}$, before analyzing dietary ratios by Bayesian mixing models.

In the present study, although the mean $\mathrm{C}: \mathrm{N}$ values of skin and muscle were lower than 3.5, lipid extraction significantly increased the $\delta^{13} \mathrm{C}$ values and lowered the C:N ratios of muscle. Similar results were found for bone tissue of loggerhead turtles, where although samples showed mean C:N ratios of 3.1, changes in $\delta^{13} \mathrm{C}$ values of $\sim 1.5 \%$ o were found after lipid extraction (Medeiros et al. 2015), thus concluding that the $\mathrm{C}: \mathrm{N}$ ratio may not accurately predict the lipid content of samples. Likewise, the reason for the use of $\mathrm{C}: \mathrm{N}$ as an indicator of the amount of lipids has been discussed in several other studies where tissues with different lipid proportions showed similar C:N ratios (Kiljunen et al. 2006, Fagan et al. 2011, RuizCooley et al. 2011, Ryan et al. 2012). This finding is also important, as most normalization models of $\delta^{13} \mathrm{C}$ values (e.g. McConnaughey \& McRoy 1979, Post et al. 2007) rely on the $\mathrm{C}: \mathrm{N}$ ratio as a proxy for the lipid content of the sample. Therefore, caution is required when applying these mathematical methods that use the $\mathrm{C}: \mathrm{N}$ ratio as a model parameter for calculating lipid-free $\delta^{13} \mathrm{C}$ values.

$\delta^{15} \mathrm{~N}$ values showed no significant differences after lipid extraction. This result was similar to that found for loggerhead sea turtle bone (Medeiros et al. 2015) and a variety of other aquatic consumers (Ingram et al. 2007, Ricca et al. 2007). However, in other studies, a change in $\delta^{15} \mathrm{~N}$ values was observed (Bodin et al. 2007, Logan et al. 2008, Lesage et al. 2010, RuizCooley et al. 2011, Wilson et al. 2014) and was associated with the extraction of lipoprotein components that have low nitrogen and the binding of proteins with structural polar lipid components (Bodin et al. 2007, Ruiz-Cooley et al. 2011). Due to the inconsistency of lipid extraction effects on $\delta^{15} \mathrm{~N}$ values, separate runs for carbon and nitrogen SIA are recommended (e.g. Post et al. 2007, Kojadinovic et al. 
2008), unfortunately doubling processing time and laboratory costs. However, our findings showed no undesired effects of lipid extraction on $\delta^{15} \mathrm{~N}$ values when analyzing skin or muscle of young sea turtles using chloroform:methanol as the solvent.

Both the low $\mathrm{C}: \mathrm{N}$ ratios as well as the lack of lipid extraction effects on carbon isotope values of skin reported in this study showed that there is no need for lipid extraction of this tissue in young green turtles. However, this recommendation may not be valid for tissues from turtles that are in other life cycle phases. During the reproductive phase, the lipid content in adult females increases in the subcutaneous layers and organs to maintain metabolism during vitellogenesis (Hamann et al. 2002). Those authors observed that the concentration of triglycerides in the plasma is lower in non-breeding females and increases at the beginning of vitellogenesis and courting. Thus, the results presented here may not be applicable for SIA of the skin of sea turtles in other development phases, and testing the need for lipid extraction in tissues in these groups is recommended.

\section{CONCLUSION}

Given the observed changes in the $\delta^{13} \mathrm{C}$ values between control and lipid-extracted muscle samples that may be biologically significant, it is recommended that the lipid content of juvenile green turtle muscle should be accounted for through chemical lipid removal. On the other hand, the lipid extraction of skin samples seems not to be a necessary step in the case of juvenile green turtles, but this procedure needs to be tested in other life stages of this species. Finally, we advise caution when using the $\mathrm{C}: \mathrm{N}$ ratio of muscle of juvenile green turtles in lipid correction models, as it may not accurately predict lipid-free $\delta^{13} \mathrm{C}$ values, at least for samples in the range of C:N ratios observed here (3.2 to 3.5). Future studies should include green turtles from other age classes/ developmental stages in order to encompass a broad range of lipid contents in these tissues.

Acknowledgements. We are indebted to the nongovernmental organization Núcleo de Educação e Monitoramento Ambiental (NEMA) for providing the samples used in this study. Analysis of the data was supported financially by the Coordenação de Aperfeiçoamento Pessoal de Nível Superior (CAPES/AuxPe). CAPES also provided a scholarship to T.F.B. S.B. is currently a postdoctoral fellow (CAPES-PNPD Institucional 2931/2011). This article is part of T.F.B.'s MSc thesis in Biological Oceanography (Graduation Course in Biological Oceanography - IO - FURG, RS, Brazil) under the supervision of M.C. and S.B. and is a contribution of the research groups 'Ecologia e Conservação da Megafauna Marinha-EcoMega/CNPq' and 'Grupo de Análises de Isótopos Estáveis em Ambientes Aquáticos (GAIA-FURG)'.

\section{LITERATURE CITED}

Almeida AP, Moreira LMP, Bruno SC, Thomé JCA, Martins AS, Bolten AB, Bjorndal KA (2011) Green turtle nesting on Trindade Island, Brazil: abundance, trends, and biometrics. Endang Species Res 14:193-201

Arthur KE, Boyle MC, Limpus CJ (2008) Ontogenetic changes in diet and habitat use in green sea turtle (Chelonia mydas) life history. Mar Ecol Prog Ser 362:303-311

Bodin F, Loc'h LE, Hily C (2007) Effect of lipid removal on carbon and nitrogen stable isotope ratios in crustacean tissues. J Exp Mar Biol Ecol 341:168-175

Bolten AB (1999) Techniques for measuring sea turtles. In: Eckert KL, Bjorndal KA, Abreu-Grobois FA, Donnelly M (eds) Research and management techniques for the conservation of sea turtles. Publication No. 4. IUCN/SSC Marine Turtle Specialist Group, Washington, DC, p 1-5

Cardona L, Aguilar A, Pazos L (2009) Delayed ontogenic dietary shift and high levels of omnivory in green turtles (Chelonia mydas) from the NW coast of Africa. Mar Biol 156:1487-1495

> Carlisle AB, Goldman KJ, Litvin SY, Madigan DJ and others (2015) Stable isotope analysis of vertebrae reveals ontogenetic changes in habitat in an endothermic pelagic shark. Proc R Soc B 282:20141446

> Cherel Y, Hobson KA, Weimerskirch H (2005) Using stable isotopes to study resource acquisition and allocation in procellariiform seabirds. Oecologia 145:533-540

DeNiro MJ, Epstein S (1977) Mechanism of carbon isotope fractionation associated with lipid synthesis. Science 197: 261-263

> DeNiro MJ, Epstein S (1978) Influence of diet on the distribution of carbon isotopes in animals. Geochim Cosmochim Acta 42:495-506

DeNiro MJ, Epstein S (1981) Influence of diet on the distribution of nitrogen isotopes in animals. Geochim Cosmochim Acta 45:341-351

Drago M, Franco-Trecu V, Zenteno L, Szteren D and others (2015) Sexual foraging segregation in South American sea lions increases during the pre-breeding period in the Río de la Plata plume. Mar Ecol Prog Ser 525:261-272

Duarte DLV, Monteiro DS, Jardim RD, Soares JCM, Varela AS Jr (2011) Sex determination and gonadal maturation of females of green turtle (Chelonia mydas) and loggerhead sea turtle (Caretta caretta) in extreme southern of Brazil. Acta Biol Parana 40:87-103

> Elliott KH, Davis M, Elliott JE (2014) Equations for lipid normalization of carbon stable isotope ratios in aquatic bird eggs. PLoS One 9:e83597

Fagan KA, Koops MA, Arts MT, Power M (2011) Assessing the utility of $\mathrm{C}: \mathrm{N}$ ratios for predicting lipid content in fishes. Can J Fish Aquat Sci 68:374-385

Folch J, Lees M, Stanley GHS (1957) A simple method for the isolation and purification of total lipids from animal tissues. J Biol Chem 226:497-509

González Carman V, Botto F, Gaitán E, Albareda D, Campagna C, Mianzan H (2014) A jellyfish diet for the herbivorous green turtle Chelonia mydas in the temperate SW Atlantic. Mar Biol 161:339-349 
Hamann M, Limpus CJ, Whittier JM (2002) Patterns of lipid storage and mobilisation in the female green sea turtle (Chelonia mydas). J Comp Physiol B 172:485-493

Ingram T, Matthews B, Harrod C, Stephens T, Grey J, Markel R, Mazumder A (2007) Lipid extraction has little effect on the $\delta^{15} \mathrm{~N}$ of aquatic consumers. Limnol Oceanogr Methods 5:338-342

Kiljunen M, Grey J, Sinisalo T, Harrod C, Immonen H, Jones RI (2006) A revised model for lipid-normalizing $\delta^{13} \mathrm{C}$ values from aquatic organisms, with implications for isotope mixing models. J Appl Ecol 43:1213-1222

Kojadinovic J, Ricjard P, Le Corre M, Bustamante P (2008) Effects of lipid extraction on $\delta^{13} \mathrm{C}$ and $\delta^{15} \mathrm{~N}$ values in seabird muscle, liver and feathers. Waterbirds 31:169-178

Lemons G, Lewison R, Komoroske L, Gaos A and others (2011) Trophic ecology of green sea turtles in a highly urbanized bay: insights from stable isotopes and mixing models. J Exp Mar Biol Ecol 405:25-32

Lesage V, Morin Y, Rioux È, Pomerleau C, Ferguson SH, Pelletier É (2010) Stable isotopes and trace elements as indicators of diet and habitat use in cetaceans: predicting errors related to preservation, lipid extraction, and lipid normalization. Mar Ecol Prog Ser 419:249-265

Logan JM, Jardine TD, Miller TJ, Bunn SE, Cunjak RA, Lutcavage ME (2008) Lipid corrections in carbon and nitrogen stable isotope analyses: comparison of chemical extraction and modelling methods. J Anim Ecol 77:838-846

> Martínez del Rio C, Wolf N, Carleton SA, Gannes LZ (2009) Isotopic ecology ten years after a call for more laboratory experiments. Biol Rev (Camb) 84:91-111

McConnaughey T, McRoy CP (1979) Food-web structure and the fractionation of carbon isotopes in the Bering Sea. Mar Biol 53:257-262

McCutchan JH, Lewis WM, Kendall C, McGrath CC (2003) Variation in trophic shift for stable isotope ratios of carbon, nitrogen, and sulfur. Oikos 102:378-390

Medeiros L, da Silveira Monteiro D, Petitet R, Bugoni L (2015) Effects of lipid extraction on the isotopic values of sea turtle bone collagen. Aquat Biol 23:191-199

Minagawa M, Wada E (1984) Stepwise enrichment of ${ }^{15} \mathrm{~N}$ along food chains: further evidence and the relation between $\delta^{15} \mathrm{~N}$ and animal age. Geochim Cosmochim Acta 48:1135-1140

Payo-Payo A, Ruiz B, Cardona L, Borrell A (2013) Effect of tissue decomposition on stable isotope signatures of striped dolphins Stenella coeruleoalba and loggerhead sea turtles Caretta caretta. Aquat Biol 18:141-147

$>$ Post DM (2002) Using stable isotopes to estimate trophic position: models, methods, and assumptions. Ecology 83 : 703-718

> Post DM, Layman CA, Arrington DA, Takimoto G, Quattrochi J, Montaña CG (2007) Getting to the fat of the matter: models, methods and assumptions for dealing with lipids in stable isotope analyses. Oecologia 152:179-189 Prior B, Booth DT, Limpus CJ (2016) Investigating diet and

Editorial responsibility: Christine Paetzold, Oldendorf/Luhe, Germany diet switching in green turtles (Chelonia mydas). Aust J Zool 63:365-375

R Development Core Team (2013) R: a language and environment for statistical computing. R Foundation for Statistical Computing, Vienna. www.R-project.org/

Revelles M, Cardona L, Aguilar A, Borrell A, Gloria F, San Félix M (2007) Stable C and N isotope concentration in several tissues of the loggerhead sea turtle Caretta caretta from the western Mediterranean and dietary implications. Sci Mar 71:87-93

Ricca MA, Miles AK, Anthony RG, Deng X, Hung SSO (2007) Effect of lipid extraction on analyses of stable carbon and stable nitrogen isotopes in coastal organisms of the Aleutian archipelago. Can J Zool 85:40-48

Ruiz-Cooley RI, Garcia KY, Hetherington ED (2011) Effects of lipid removal and preservatives on carbon and nitrogen isotope ratios on squid tissues: implications for ecological studies. J Exp Mar Biol Ecol 407:101-107

Ryan C, McHugh B, Trueman CN, Harrod C, Berrow SD, $\mathrm{O}^{\prime}$ Connor I (2012) Accounting for the effects of lipids in stable isotope $\left(\delta^{13} \mathrm{C}\right.$ and $\delta^{15} \mathrm{~N}$ values) analysis of skin and blubber of balaenopterid whales. Rapid Commun Mass Spectrom 26:2745-2754

Sotiropoulos MA, Tonn WN, Wassenaar LI (2004) Effects of lipid extraction on stable carbon and nitrogen isotope analyses of fish tissues: potential consequences for foodweb studies. Ecol Freshw Fish 13:155-160

> Sweeting CJ, Polunin NVC, Jennings S (2006) Effects of chemical lipid extraction and arithmetic lipid correction on stable isotope ratios of fish tissues. Rapid Commun Mass Spectrom 20:595-601

> Thomson JA, Heithaus MR, Burkholder DA, Vaudo JJ, Wirsing AJ, Dill LM (2012) Site specialists, diet generalists? Isotopic variation, site fidelity, and foraging by loggerhead turtles in Shark Bay, Western Australia. Mar Ecol Prog Ser 453:213-226

Todd SK, Holm B, Rosen DAS, Tollit DJ (2010) Stable isotope signal homogeneity and differences between and within pinniped muscle and skin. Mar Mamm Sci 26:176-185

Tomaszewicz CNT, Seminoff JA, Ramirez MD, Kurle CM (2015) Effects of demineralization on the stable isotope analysis of bone samples. Rapid Commun Mass Spectrom 29:1879-1888

Vanderklift MA, Ponsard S (2003) Sources of variation in consumer-diet ${ }^{15} \mathrm{~N}$ enrichments: a meta-analysis. Oecologia 136:169-182

Wilson RM, Chanton JP, Balmer BC, Nowacek DP (2014) An evaluation of lipid extraction techniques for interpretation of carbon and nitrogen isotope values in bottlenose dolphin (Tursiops truncatus) skin tissue. Mar Mamm Sci 30:85-103

Yurkowski DJ, Hussey NE, Semeniuk C, Ferguson SH, Fisk AT (2015) Effects of lipid extraction and the utility of lipid normalization models on $\delta^{13} \mathrm{C}$ and $\delta^{15} \mathrm{~N}$ values in Arctic marine mammal tissues. Polar Biol 38:131-143

Submitted: September 7, 2015; Accepted: March 29, 2016

Proofs received from author(s): April 19, 2016 